\title{
Kompleksitas Operasi Perusahaan sebagai Pemoderasi Pengaruh Pergantian Auditor dan Financial Distress terhadap Audit Delay
}

\section{Siti Fatimah ${ }^{1}$ \\ I Dewa Nyoman Wiratmaja ${ }^{2}$}

${ }^{1}$ Fakultas Ekonomi dan Bisnis Universitas Udayana (Unud), Bali, Indonesia. email: sitifatimah171717@gmail.com / Telp: +62 89614427317.

${ }^{2}$ Fakultas Ekonomi dan Bisnis Universitas Udayana (Unud), Bali, Indonesia.

\begin{abstract}
ABSTRAK
Tujuan penelitian ini adalah untuk mengetahui pengaruh pergantian auditor dan financial distress pada audit delay, serta kompleksitas operasi perusahaan sebagai pemoderasi pengaruh pergantian auditor dan financial distress pada audit delay. Penelitian ini dilakukan di perusahaan consumer goods yang terdaftar di Bursa Efek Indonesia (BEI) dari tahun 2011-2016. Sampel yang diambil sebanyak 156 perusahaan dengan menggunakan teknik purposive sampling. Pengumpulan data dilakukan dengan metode observasi non partisipan. Teknik analisis yang digunakan adalah Moderated Regression Analysis (MRA). Hasil analisis menyatakan bahwa pergantian auditor tidak berpengaruh pada audit delay, sedangkan financial distress berpengaruh positif pada audit delay. Kompleksitas operasi perusahaan ternyata tidak memoderasi hubungan pergantian auditor dan financial distress pada audit delay.

Kata Kunci: Audit Delay, Pergantian Auditor, Financial Distress, Kompleksitas Operasi Perusahaan
\end{abstract}

\begin{abstract}
The purpose of this study was to determine the effect of auditor switching and financial distress on audit delay, as well as complexity of operations of the company as a moderating influence auditor switching and financial distress on audit delay. This research was conducted in consumer goods companies listed on the Indonesian Stock Exchange (BEI) of the year 2011-2016. Samples taken as many as 156 companies using purposive sampling technique. The data collection was conducted using non-participant observation. The analysis technique used is Moderated Regression Analysis (MRA). Analysis results showed that auditor switching have no affect audit delay, while financial distress positively affect audit delay. Complexity of operations of the company was not able to moderate the relationship between auditor switching and financial distress with audit delay.

Keywords: Audit Delay, Auditor Switching, Financial Distress, Complexity of Operations of the Company
\end{abstract}

\section{PENDAHULUAN}

Perkembangan aktivitas pada Bursa Efek Indonesia (BEI) semakin meningkat yang ditandai dengan berkembangnya perusahaan go public di Indonesia. Perusahaan yang tercatat pada BEI diwajibkan untuk patuh dalam menyampaikan laporan keuangan yang telah diaudit secara berkala dan mempublikasikan laporan 
keuangan auditannya sebagai bentuk tanggung jawab manajemen kepada investor, agar investor dapat menilai kinerja dari perusahaan publik. Kepatuhan untuk menyampaikan laporan keuangan auditan secara tepat waktu dipertegas dengan adanya peraturan mengenai batas waktu maksimum yang diwajibkan bagi emiten untuk menyampaikan laporan keuangan yang telah diaudit kepada pihak-pihak yang berkepentingan.

Peraturan penyampaian laporan keuangan tahunan yang berlaku yaitu Peraturan Otoritas Jasa Keuangan Nomor 29/PJOK.04/2016 tentang laporan tahunan emiten atau perusahaan publik yang menggantikan Keputusan Ketua Badan Pengawas Pasar Modal dan Lembaga Keuangan Nomor KEP-431/BL/2012 tanggal 1 Agustus 2012 tentang penyampaian laporan tahunan emiten atau perusahaan publik beserta peraturan nomor X.K.6 yang merupakan lampirannya dicabut dan dinyatakan tidak berlaku pada tanggal 1 Januari 2017. Peraturan Otoritas Jasa Keuangan Nomor 29/PJOK.04/2016 pada Pasal 7 ayat (1) menyatakan Emiten atau Perusahaan Publik wajib menyampaikan laporan tahunan kepada Otoritas Jasa Kuangan (OJK) paling lambat pada akhir bulan keempat setelah tahun buku berakhir dan Pasal 10 ayat (6) menyatakan dalam hal laporan tahunan dalam bentuk dokumen cetak dan dokumen elektronik disampaikan secara terpisah, penghitungan ketepatan waktu penyampaian Laporan Tahunan didasarkan pada Laporan Tahunan yang lebih dahulu diterima oleh OJK. Adanya peraturan tersebut tidak cukup membuat perusahaan tepat waktu dalam penyampaian laporan keuangan. Realitanya masih banyak perusahaan yang terlambat mempublikasikan laporan keuangannya tersebut, khususnya yang terjadi 
di BEI, hal ini sebagian besar disebabkan oleh lamanya waktu penyelesaian audit (Puspitasari dan Latrini, 2014).

Keterlambatan penyajian laporan keuangan auditan oleh emiten di BEI masih tetap terjadi sepanjang tahun 2011 sampai dengan 2016. Tahun 2012, terdapat sekitar 54 emiten yang terlambat melaporkan laporan keuangan auditan tahun 2011 (Merdeka, 2012). Tahun 2013, sebanyak 52 emiten yang terlambat melaporkan laporan keuangan audit periode 2012 (Kontan, 2013). Tahun 2014, sebanyak 57 emiten yang terlambat melaporkan laporan keuangan audit tahun 2013 (Kontan, 2014). Tahun 2015, sebanyak 52 emiten yang terlambat melaporkan laporan keuangan audit periode 2014 (Neraca, 2015). Tahun 2016, sebanyak 63 emiten yang terlambat melaporkan laporan keuangan audit periode 2015. Sementara pada tahun 2017, sebanyak 17 emiten terkena suspensi. Suspensi tersebut dilakukan karena emiten tersebut belum menyampaikan laporan keuangan auditan periode 2016, selain itu belum menyampaikan denda atas keterlambatan penyampaian laporan keuangan itu (Liputan6, 2016).

Walaupun telah ditetapkannya peraturan yang cukup ketat mengenai kualitas, kuantitas, dan ketepatan waktu penyampaian laporan keuangan. Di sisi lain, auditing merupakan kegiatan yang membutuhkan waktu karena pemeriksaan laporan keuangan oleh auditor independen diwajibkan memenuhi standar audit dan tanggung jawab atas opini audit sehingga adakalanya waktu penyelesaian audit dan penyampaian laporan keuangan auditan tertunda. Perbedaan waktu antara tanggal laporan keuangan dengan tanggal opini audit dalam laporan keuangan mengindikasikan tentang lamanya waktu penyelesaian audit yang 
Siti Fatimah dan I Dewa Nyoman Wiratmaja. Kompleksitas...

dilakukan. Perbedaan waktu ini dalam audit sering disebut dengan audit delay (Praptika dan Rasmini, 2016).

Menurut Ashton et al. (1987) "Audit delay is number of calendar days from fiscal year-end to date of auditor's report". Saputri (2012) mendefinisikan audit delay sebagai lama waktu penyelesaian audit yang dilaksanakan oleh auditor dilihat dari perbedaan tanggal tutup tahun buku laporan keuangan (biasanya 31 Desember) sampai dengan tanggal opini audit dalam laporan keuangan auditan. Semakin lama auditor dalam menyelesaikan pekerjaan auditnya maka semakin panjang audit delay. Namun sebaliknya, jika semakin cepat pekerjaan audit yang dilakukan auditor, maka akan semakin pendek periode audit delay (Muliantari dan Latrini, 2017). Audit report lag yang berlebihan akan membahayakan kualitas pelaporan keuangan dengan tidak memberikan informasi yang tepat waktu kepada investor serta mengurangi tingkat kepercayaan investor terhadap pasar (Hashim dan Rahman, 2011).

Faktor yang dapat menimbulkan audit delay adalah pergantian auditor. Ahmed dan Hossain (2010) menyatakan bahwa pergantian auditor merupakan putusnya hubungan auditor yang lama dengan perusahaan kemudian mengangkat auditor yang baru untuk menggantikan auditor yang lama. Pergantian auditor pada suatu perusahaan dilakukan dengan tujuan untuk menjaga independensi dari auditor agar tetap bersikap objektif dalam melakukan tugasnya sebagai auditor. Perusahaan yang mengalami pergantian auditor akan mengangkat auditor yang baru, dimana butuh waktu yang cukup lama bagi auditor yang baru dalam 
mengenali karakteristik usaha klien dan sistem yang ada didalamnya (Tambunan, 2014).

Hasil penelitian yang dilakukan oleh Rustiarini dan Sugiarti (2013), Praptika dan Rasmini (2016), serta Verawati dan Wirakusuma (2016) menyatakan bahwa pergantian auditor berpengaruh positif terhadap audit delay, berbeda dalam penelitian yang dilakukan oleh Putra dan Sukirman (2014), Tambunan (2014), serta Megayanti dan Budiartha (2016) yang menyatakan bahwa variabel auditor switching tidak berpengaruh terhadap audit delay.

Audit delay bertambah apabila penerbitan laporan keuangan mengalami penundaan. Penundaan tersebut dapat terjadi karena terdapat berita buruk dalam laporan keuangan. Kesulitan keuangan (financial distress) merupakan salah satu berita buruk dalam laporan keuangan. Financial distress didefinisikan sebagai tahap penurunan kondisi keuangan yang terjadi sebelum terjadinya kebangkrutan ataupun likuidasi (Platt dan Platt, 2002). Suatu perusahaan dapat dikatakan berada dalam kondisi financial distress atau kesulitan keuangan ketika perusahaan tersebut mempunyai laba bersih negatif selama beberapa tahun (Whitaker, 1999).

Menurut Praptika dan Rasmini (2016), kondisi financial distress yang terjadi pada perusahaan dapat meningkatkan risiko audit pada auditor independen khususnya risiko pengendalian dan risiko deteksi. Dengan meningkatnya risiko itu maka auditor harus melakukan pemeriksaan risiko (risk assessment) sebelum menjalankan proses audit, tepatnya pada fase perencanaan audit (audit planning). Sehingga hal ini dapat mengakibatkan lamanya proses audit dan berdampak pada bertambahnya audit delay. Hasil penelitian yang dilakukan Julien (2013) 
Siti Fatimah dan I Dewa Nyoman Wiratmaja. Kompleksitas...

menyatakan bahwa financial distress tidak memiliki pengaruh terhadap audit report lag, sedangkan penelitian dari Praptika dan Rasmini (2016) serta Muliantari dan Latrini (2017) menghasilkan financial distress berpengaruh secara positif terhadap audit delay.

Kompleksitas operasi perusahaan dapat memicu terjadinya audit delay. Menurut Ahmad dan Abidin (2008), antara kompleksitas perusahaan yang dilihat dari diversifikasi bisnis operasi klien dan jumlah anak perusahaan klien berdampak pada ketepatan waktu pelaporan keuangan, hal tersebut dikarenakan auditor akan menghabiskan lebih banyak waktu untuk menyelesaikan tugas audit pada perusahaan klien yang mengalami peningkatan kompleksitas perusahaan. Hossain dan Taylor (1998) menyatakan bahwa di negara berkembang, khususnya Pakistan, anak perusahaan memerlukan waktu yang relatif lebih cepat dalam melakukan audit laporan keuangannya dibandingkan dengan perusahaan induknya. Perusahaan anak (subsidiari) perlu mempersiapkan laporan keuangan segmentasinya sesegera mungkin kepada perusahaan induk dalam rangka pembuatan laporan keuangan konsolidasi pada akhir tahun periode akuntansi, kemudian selanjutnya auditor mengaudit laporan konsolidasi perusahaan tersebut. Hal ini akan membuat lingkup audit yang akan dilakukan oleh auditor semakin luas, sehingga berdampak pada waktu yang dibutuhkan oleh auditor dalam menyelesaikan tugas auditnya.

Hasil penelitian yang dilakukan oleh Widyastuti dan Astika (2017), Ariyani dan Budiartha (2014), Hassan (2016), serta Darmawan dan Widhiyani (2017) menunjukkan secara individual variabel kompleksitas operasi perusahaan 
berpengaruh positif dan signifikan terhadap audit delay. Namun berbeda dengan penelitian dari Angruningrum dan Wirakusuma (2013) serta Widosari dan Rahardja (2012) yang menghasilkan kompleksitas operasi perusahaan tidak mempunyai pengaruh signifikan terhadap audit delay.

Perbedaan penelitian ini dengan penelitian sebelumnya yaitu terletak pada kompleksitas operasi perusahaan yang ditempatkan sebagai variabel moderating, hal ini dikarenakan adanya ketidakkonsistenan hasil penelitian. Kompleksitas operasi perusahaan dipilih menjadi variabel pemoderasi karena hal ini merupakan salah satu faktor yang memengaruhi audit delay. Kompleksitas operasi perusahaan menggambarkan bisnis operasi klien yang beranekaragam dan banyaknya jumlah anak perusahaan klien. Apabila perusahaan yang mengalami peningkatan kompleksitas operasi perusahaan melakukan pergantian auditor maupun berada dalam kondisi financial distress maka kemungkinan perusahaan untuk tidak tepat waktu dalam mempublikasikan laporan keuangan akan semakin besar.

Rumusan masalah penelitian ini yaitu bagaimana pengaruh pergantian auditor dan financial distress terhadap audit delay, serta bagaimana kompleksitas operasi perusahaan memoderasi pengaruh pergantian auditor dan financial distress terhadap audit delay. Tujuan penelitian yakni untuk memperoleh bukti empiris pengaruh pergantian auditor dan financial distress terhadap audit delay, serta mendapatkan bukti empiris kemampuan kompleksitas operasi perusahaan memoderasi pengaruh pergantian auditor dan financial distress terhadap audit delay. 
Siti Fatimah dan I Dewa Nyoman Wiratmaja. Kompleksitas...

Manfaat teoretis dari penelitian yaitu diharapkan dapat memberikan tambahan referensi, informasi dan wawasan untuk mendukung penelitian selanjutnya yang berkaitan dengan audit delay, serta menjadi tambahan pengetahuan mengenai kompleksitas operasi perusahaan sebagai pemoderasi pengaruh pergantian auditor dan financial distress terhadap audit delay. Manfaat praktis yaitu diharapkan dapat memberikan manfaat bagi pihak-pihak yang berkepentingan, seperti akuntan publik dan Kantor Akuntan Publik (KAP) serta untuk meningkatkan efisiensi dan efektivitas pelaksanaan audit dengan mengelola faktor-faktor yang memengaruhi audit delay, sehingga dapat mempublikasikan laporan keuangan secara tepat waktu.

Teori keagenan adalah teori yang menjelaskan hubungan antara pihak agen (manajemen) dengan prinsipal (pemegang saham). Jensen dan Meckling (1976) menyatakan hubungan agensi muncul ketika satu orang atau lebih mempekerjakan orang lain untuk memberikan jasa, kemudian mendelegasikan wewenang pengambilan keputusan bagi perusahaan, maka pada saat itulah hubungan keagenan muncul. Audit delay mempunyai hubungan erat dengan ketepatan waktu publikasi laporan keuangan, karena manfaat laporan keuangan menjadi berkurang nilainya apabila tidak disampaikan secara tepat waktu. Berkurangnya nilai informasi yang disampaikan kepada prinsipal menimbulkan asimetris informasi, dalam hal ini pihak agen dapat melakukan kecurangan dengan memanipulasi data karena pihak agen lebih banyak mengetahui informasi internal perusahaan secara detail dibandingkan pihak prinsipal yang hanya mengetahui informasi perusahaan secara eksternal melalui hasil kinerja yang dibuat oleh manajemen. Oleh karena 
itu, hal ini memerlukan ketepatan waktu untuk mengurangi adanya asimetris informasi antara pihak agen atau manajemen dengan pihak prinsipal atau pemegang saham, sehingga laporan keuangan dapat disampaikan secara transparan kepada prinsipal (Praptika dan Rasmini, 2016).

Teori sinyal mengemukakan tentang bagaimana sebuah perusahaan memberikan sinyal kepada pengguna laporan keuangan. Sinyal ini merupakan informasi mengenai apa yang sudah dilakukan oleh manajemen untuk merealisasikan keinginan pemilik. Ross (1977) menyatakan bahwa pihak eksekutif perusahaan memiliki informasi lebih baik mengenai perusahaannya akan terdorong untuk menyampaikan informasi tersebut kepada calon investor agar harga saham perusahaan meningkat. Teori sinyal bermanfaat dalam menjelaskan audit delay, dimana laporan keuangan tahunan yang telah diaudit dan dipublikasikan kepada pihak publik tepat pada waktunya dapat memberikan sinyal bahwa perusahaan mempunyai informasi yang bermanfaat atau memiliki good news. Namun sebaliknya, semakin lama audit delay menyebabkan kurang bergunanya informasi dalam pengambilan keputusan karena informasi kehilangan sifat relevannya. Lamanya audit delay memberikan sinyal bahwa perusahaan memiliki bad news sehingga perusahaan cenderung tidak tepat waktu dalam menyampaikan laporan keuangannya.

Pergantian auditor mendapat perhatian yang serius bagi perusahaan saat ini karena perusahaan mengalami kekhawatiran pada auditor baru yang melakukan pemeriksaan terhadap sistem pembukuan dan menilai rendah standar mutu pembukuan perusahaan (Praptika dan Rasmini, 2016). Beberapa hal yang 
Siti Fatimah dan I Dewa Nyoman Wiratmaja. Kompleksitas...

dapat menyebabkan pergantian auditor seperti berakhirnya kontrak kerja tanpa adanya perpanjangan penugasan baru, konflik kepentingan antara pemilik perusahaan dan manajemen perusahaan yang memicu pergantian manajemen dan pergantian auditor, ataupun pergantian auditor dilakukan agar bisa bekerjasama dan mendapatkan opini sesuai dengan keinginan manajemen untuk dipertanggungjawabkan dalam RUPS (Srimindarti, 2006).

Apabila perusahaan mengalami pergantian auditor, tentunya auditor baru membutuhkan waktu yang cukup lama untuk mengenali karakteristik usaha klien dan sistem yang ada didalamnya sehingga hal ini menyita waktu auditor dalam melaksanakannya proses auditnya. Hasil penelitian yang dilakukan oleh Rustiarini dan Sugiarti (2013) membuktikan bahwa pergantian auditor berpengaruh secara positif terhadap audit report lag. Sejalan dengan penelitian tersebut, penelitian yang dilakukan oleh Verawati dan Wirakusuma (2016) serta Praptika dan Rasmini (2016) menyatakan bahwa pergantian auditor berpengaruh positif terhadap audit delay, dimana keterlambatan pelaporan audit akan menyebabkan keterlambatan perusahaan dalam mempublikasikan laporan keuangan. Berdasarkan uraian tersebut, maka dapat dirumuskan hipotesis sebagai berikut.

$\mathrm{H}_{1}$ : Pergantian auditor berpengaruh positif terhadap audit delay.

Kesulitan keuangan (financial distress) merupakan salah satu berita buruk yang akan memengaruhi kondisi perusahaan di mata publik. Elloumi dan Gueyie (2001) mengkategorikan suatu perusahaan sedang mengalami financial distress apabila perusahaan tersebut selama dua tahun berturut-turut mengalami laba 
bersih negatif. Penelitian lain dilakukan oleh Baldwin dan Scott (1983), berpendapat bahwa suatu perusahaan mengalami financial distress apabila perusahaan tersebut tidak dapat memenuhi kewajiban keuangannya dengan dilanggarnya persyaratan hutang disertai penghapusan atau pengurangan pembiayaan dividen. Berbeda dengan Wruck (1990) yang menyatakan bahwa perusahaan mengalami financial distress sebagai akibat dari permasalahan ekonomi, penurunan kinerja dan manajemen yang buruk.

Kondisi financial distress yang terjadi pada perusahaan dapat meningkatkan risiko audit pada auditor independen khususnya risiko pengendalian dan risiko deteksi. Dengan meningkatnya risiko itu maka auditor harus melakukan pemeriksaan risiko (risk assessment) sebelum menjalankan proses audit, tepatnya pada fase perencanaan audit (audit planning). Sehingga hal ini dapat mengakibatkan lamanya proses audit dan berdampak pada bertambahnya audit delay (Praptika dan Rasmini, 2016). Aziz dan Dar (2006) mengungkapkan ciri-ciri perusahaan yang mengalami kesulitan keuangan adalah sebagai berikut: terdapat perubahan signifikan dalam komposisi aset dan kewajiban dalam neraca, arus kas negatif, dan nilai perbandingan yang tinggi antara hutang dengan aset.

Perusahaan yang mengalami kesulitan keuangan (financial distress) cenderung menyampaikan laporan keuangannya tidak tepat waktu dibandingkan perusahaan yang tidak mengalami kesulitan keuangan. Hal tersebut juga didukung oleh penelitian yang dilakukan Praptika dan Rasmini (2016) serta Muliantari dan Latrini (2017) yang menyatakan bahwa financial distress 
berpengaruh positif dan signifikan terhadap audit delay. Berdasarkan uraian tersebut, maka dapat dirumuskan hipotesis sebagai berikut.

$\mathrm{H}_{2}$ : Financial Distress berpengaruh positif terhadap audit delay.

Ahmed dan Hossain (2010) menyatakan bahwa pergantian auditor merupakan putusnya hubungan auditor yang lama dengan perusahaan kemudian mengangkat auditor yang baru untuk menggantikan auditor yang lama. Ketika auditor baru ditugaskan mengaudit suatu perusahaan untuk pertama kalinya maka ia harus memiliki pemahaman terhadap karakteristik industri perusahaan tersebut. Kemudian auditor harus melakukan pengujian ketaataan (compliance test) terlebih dahulu pada perusahaan baru tersebut sebelum melakukan substantive test, dimana compliance test diperlukan untuk membuktikan efektif atau tidaknya pengendalian intern suatu perusahaan. Auditor baru membutuhkan lebih banyak waktu untuk melakukan pemeriksaan pada perusahaan yang pertama kali ia audit dibandingkan dengan auditor yang telah melakukan penugasan berulang pada perusahaan tersebut. Pergantian auditor sesungguhnya dapat menimbulkan audit delay, karena tugas dari auditor baru tersebut tidak dapat diselesaikan dengan tepat waktu.

Jika suatu perusahaan melakukan pergantian auditor pada perusahaan yang mengalami peningkatan kompleksitas maka penyampaian laporan keuangan auditan menjadi terlambat. Hal ini dikarenakan semakin tinggi kompleksitas suatu perusahaan, maka semakin banyak waktu yang dibutuhkan auditor untuk memahami karakteristik usaha klien, sistem yang digunakan, dan menguji kuat lemahnya struktur pengendalian intern perusahaan, dimana auditor juga harus 
melihat jumlah anak dari perusahaan klien tersebut. Berdasarkan uraian tersebut, maka dapat dirumuskan hipotesis sebagai berikut.

$\mathrm{H}_{3}$ : Kompleksitas operasi perusahaan memperkuat pengaruh pergantian auditor terhadap audit delay.

Financial distress adalah sebuah kondisi dimana perusahaan sedang menghadapi masalah kesulitan keuangan. Sebuah perusahaan yang mengalami financial distress memiliki kecenderungan untuk melakukan manipulasi terhadap laporan keuangannya, sehingga auditor akan menetapkan risiko audit yang lebih tinggi terhadap perusahaan yang mengalami kesulitan keuangan. Maka dari itu, auditor akan melakukan penerapan audit dengan sangat hati-hati, teliti, dan cermat. Kemudian seorang auditor akan mengambil ruang sampel yang lebih luas hal ini dikarenakan risiko audit dan salah saji material diperusahaan yang mengalami financial distress lebih tinggi dibandingkan dengan perusahaan yang dalam kondisi baik-baik saja. Sehingga hal ini akan berdampak pada keterlambatan waktu penyampaian laporan keuangan. Hubungan tersebut didukung juga oleh penelitian Praptika dan Rasmini (2016) yang menentukan bahwa financial distress berpengaruh positif terhadap audit delay.

Apabila perusahaan yang kompleksitasnya tinggi mengalami financial distress, maka akan memakan waktu lebih banyak untuk menerbitkan laporan keuangannya. Auditor memeriksa setiap transaksi dan catatan yang menyertainya dengan banyaknya anak perusahaan yang dimiliki oleh perusahaan klien tersebut. Hal ini akan membuat lingkup audit yang akan dilakukan oleh auditor semakin luas, sehingga hal ini akan berdampak pada waktu yang dibutuhkan oleh auditor dalam menyelesaikan tugas auditnya dan berdampak pada bertambahnya audit 
delay. Berdasarkan uraian tersebut, maka dapat dirumuskan hipotesis sebagai berikut.

$\mathrm{H}_{4}$ : Kompleksitas operasi perusahaan memperkuat pengaruh financial distress terhadap audit delay.

\section{METODE PENELITIAN}

Penelitian yang digunakan dalam penelitian ini adalah pendekatan kuantitatif yang berbentuk asosiatif dengan tipe kausalitas merupakan jenis penelitian yang menjelaskan pengaruh variabel independen terhadap variabel dependen (Sugiyono, 2016:12). Ruang lingkup penelitian ini terbatas pada perusahaan consumer goods yang terdaftar di Bursa Efek Indonesia (BEI) pada tahun 20112016 melalui web resmi $w w w . i d x . c o . i d$. Objek penelitian dalam penelitian ini adalah audit delay yang dipengaruhi pergantian auditor dan financial distress dengan kompleksitas operasi perusahaan sebagai variabel moderasi pada perusahaan consumer goods yang terdaftar di BEI pada tahun 2011-2016.

Audit delay diukur secara kuantitatif dalam jumlah hari, dihitung dari tanggal tutup buku sampai tanggal pada laporan auditor. Pergantian auditor diukur dengan variabel dummy, perusahaan yang melakukan pergantian auditor selama periode penelitian diberi kode 1 dan perusahaan yang tidak melakukan pergantian auditor diberi kode 0 . Kompleksitas operasi perusahaan dapat diukur dengan menggunakan jumlah anak perusahaan yang dimiliki oleh perusahaan sampel. Financial distress (kesulitan keuangan) yang dimaksud dalam penelitian ini adalah besarnya hutang perusahaan yang digunakan untuk membiayai kinerja perusahaan yang biasa disebut dengan rasio gearing. Owusu dan Ansah (2000) mengemukakan bahwa rasio gearing dihitung melalui perbandingan jumlah 
hutang jangka panjang perusahaan dengan total aset yang dimiliki oleh perusahaan. Tingginya rasio gearing mencerminkan tingginya risiko keuangan perusahaan. Risiko keuangan perusahaan yang tinggi mengindikasikan bahwa perusahaan mengalami kesulitan keuangan.

$$
\text { FinancialDistress }=\frac{\text { Hutang Jangka Panjang }}{\text { Total Aset }}
$$

Jenis data pada penelitian ini yaitu data kualitatif yang meliputi namanama perusahaan consumer goods yang terdaftar di BEI tahun 2011-2016 dan nama akuntan publik yang mengaudit perusahaan tersebut dan data kuantitatif yang meliputi tanggal laporan auditor independen, nilai hutang jangka panjang dan total aset dari perusahaan consumer goods yang terdaftar di BEI tahun 20112016. Populasi penelitian ini yaitu 33 perusahaan consumer goods yang terdaftar di BEI tahun 2011-2016.

Populasi yang digunakan dalam penelitian ini adalah perusahaan consumer goods yang terdaftar di BEI pada tahun 2011-2016. Sampel yang diambil adalah perusahaan consumer goods yang terdaftar di BEI periode 2011-2016 dengan beberapa kriteria dalam pemilihan sampelnya. Metode penentuan sampel (sampling method) yang digunakan dalam penelitian ini adalah nonprobability sampling dengan teknik purposive sampling.

Metode pengumpulan data yang digunakan adalah metode observasi non partisipan dimana peneliti tidak terlibat secara langsung dalam proses observasi tapi hanya sebagai pengamat independen. Penelitian ini menggunakan teknik 
analisis data Moderated Regression Analysis (MRA), persamaan yang digunakan pada penelitian ini adalah sebagai berikut.

$Y=\alpha+\beta_{1} X_{1}+\beta_{2} X_{2}+\beta_{3} X_{3}+\beta_{4} X_{1} X_{3}+\beta_{5} X_{2} X_{3}+\varepsilon$

$\mathrm{Y} \quad=$ audit delay

$\alpha \quad=$ nilai konstanta

$\mathrm{X}_{1} \quad=$ pergantian auditor

$\mathrm{X}_{2} \quad=$ financial distress

$\mathrm{X}_{3} \quad=$ kompleksitas operasi perusahaan

$\mathrm{X}_{1} \mathrm{X}_{3}=$ interaksi pergantian auditor dan kompleksitas operasi perusahaan

$\mathrm{X}_{2} \mathrm{X}_{3}=$ interaksi financial distress dan kompleksitas operasi perusahaan

$\beta \quad=$ koefisien regresi

$\varepsilon \quad=$ standard error

\section{HASIL DAN PEMBAHASAN}

Perusahaan consumer goods terdiri dari 5 sub sektor, yaitu sub sektor makanan dan minuman, sub sektor rokok, sub sektor farmasi, sub sektor kosmetik dan keperluan rumah tangga, dan sub sektor peralatan rumah tangga. Perusahaan yang dapat dijadikan sampel adalah sebanyak 26 perusahaan dengan total 156 sampel amatan yang ditunjukan dengan proses seleksi sebagai berikut.

\section{Tabel 1.}

Proses dan Hasil Seleksi Sampel berdasarkan Kriteria

\begin{tabular}{|c|c|c|}
\hline & Keterangan & Jumlah \\
\hline 1 & $\begin{array}{l}\text { Jumlah perusahaan consumer goods yang terdaftar di BEI pada tahun 2011- } \\
2016\end{array}$ & 33 \\
\hline 2 & $\begin{array}{l}\text { Perusahaan consumer goods yang mengalami delisting di BEI selama periode } \\
\text { tahun 2011-2016 }\end{array}$ & (1) \\
\hline 3 & $\begin{array}{l}\text { Perusahaan consumer goods yang tidak mempublikasikan laporan auditor } \\
\text { independen dan laporan keuangannya selama periode tahun 2011-2016 }\end{array}$ & (5) \\
\hline 4 & Perusahaan consumer goods yang periode akhir buku tidak pada 31 Desember & (1) \\
\hline 5 & $\begin{array}{l}\text { Perusahaan consumer goods yang dalam laporan keuangannya tidak } \\
\text { dinyatakan dalam Rupiah. }\end{array}$ & $(0)$ \\
\hline \multicolumn{2}{|c|}{ Total sampel penelitian } & 26 \\
\hline \multicolumn{2}{|c|}{ Total pengamatan } & 6 \\
\hline \multicolumn{2}{|c|}{ Total sampel selama periode penelitian } & 156 \\
\hline
\end{tabular}

Statistik deskriptif disajikan untuk memberikan informasi mengenai karakteristik variabel-variabel penelitian, yaitu jumlah sampel, nilai maksimum, 
ISSN: 2302-8556

E-Jurnal Akuntansi Universitas Udayana

Vol.25.2.November (2018): 1205-1233

nilai minimum, nilai rata-rata, dan standar deviasi. Hasil statistik deskriptif pada penelitian ini disajikan sebagai berikut.

Tabel 2.

Hasil Uji Statistik Deskriptif

\begin{tabular}{lrrrrr}
\hline & N & Minimum & Maximum & Mean & Std. Deviation \\
\hline X1 & 156 & 0 & 1 & .51 & .50 \\
X2 & 156 & .02 & .97 & .14 & .16 \\
X3 & 156 & 0 & 112 & 9.33 & 19.59 \\
Y & 156 & 37 & 172 & 75.01 & 15.92 \\
Valid N & 156 & & & & \\
(listwise) & & & & & \\
Sumber: Data diolah, 2018 & &
\end{tabular}

Berdasarkan Tabel 2 dapat disimpulkan bahwa audit delay (Y) memiliki rentang penyelesaian audit minimum sebesar 37 dan maksimum sebesar 172 . Rata-rata penyelesaian audit secara keseluruhan yaitu sebesar 75,01 dengan standar deviasi sebesar 15,92. Perusahaan consumer goods yang terdaftar di BEI dengan audit delay minimum adalah Nippon Indosari Corporindo Tbk pada tahun 2012 dan audit delay maksimal adalah Merck Sharp Dohme Pharma pada tahun 2016.

Pergantian auditor (X1) memiliki nilai minimum 0, yaitu sampel tidak melakukan pergantian auditor dan nilai maksimum 1 yaitu sampel melakukan pergantian auditor. Nilai rata-rata pergantian auditor sebesar 51, artinya sebesar $51 \%$ perusahaan yang menjadi sampel melakukan pergantian auditor sedangkan sebesar $49 \%$ sampel tidak melakukan pergantian audior, dengan standar deviasi sebesar 0,50 .

Financial distress (X2) memiliki nilai minimum sebesar 0,02 dan nilai maksimum sebesar 0,97 . Nilai rata-rata financial distress adalah sebesar 0,14 dengan standar deviasi sebesar 0,16. Perusahaan consumer goods yang terdaftar 
Siti Fatimah dan I Dewa Nyoman Wiratmaja. Kompleksitas...

di BEI yang dijadikan sampel penelitian dengan financial distress paling kecil adalah Kalbe Farma Tbk tahun 2013 dan yang paling besar pada Bentoel International Investama Tbk tahun 2015.

Kompleksitas operasi perusahaan (X3) memiliki nilai minimum 0 dan nilai maksimum 112. Rata-rata kompleksitas operasi perusahaan adalah 9,33 dengan standar deviasi sebesar 19,59. Perusahaan consumer goods yang terdaftar di BEI yang dijadikan sampel penelitian memiliki nilai minimum menunjukkan bahwa terdapat perusahaan yang tidak memiliki anak perusahaan diantaranya adalah Wilmar Cahaya Indonesia Tbk, Merck Indonesia Tbk, Pyridam Farma Tbk, Merck Sharp Dohme Pharma Tbk, Akasha Wira International Tbk , Mandom Indonesia Tbk, Kedaung Indah Can Tbk, dan Langgeng Makmur Industry Tbk. Sedangkan nilai maksimum menunjukkan bahwa perusahaan yang memiliki anak perusahaan terbanyak adalah Indofood Sukses Makmur Tbk.

Sebelum melakukan pengujian hipotesis, penting terlebih dahulu untuk melakukan uji asumsi klasik yang meliputi uji normalitas, uji autokorelasi, uji multikolinearitas, dan uji heteroskedastisitas. Hasil uji asumsi klasik pada penelitian ini disajikan sebagai berikut.

Tabel 3.

Rekapitulasi Hasil Uji Asumsi Klasik

\begin{tabular}{ccclcc}
\hline \multirow{2}{*}{ Variabel } & Normalitas & Autokorelasi & \multicolumn{2}{c}{ Multikolinearitas } & Heteroskedastisitas \\
\cline { 2 - 6 } & $\begin{array}{c}\text { Asymp. Sig. 2 } \\
\text { tailed }\end{array}$ & DW & Tolerance & VIF & Sig. \\
\hline X1 & & & .785 & 1.273 & .442 \\
X2 & & & .712 & 1.404 & .103 \\
X3 & .258 & 2.031 & .135 & 7.427 & .180 \\
X1.X3 & & & .188 & 5.319 & .920 \\
X2.X3 & & & .109 & 9.171 & .659 \\
\hline
\end{tabular}

Sumber: Data diolah, 2018 
Berdasarkan Tabel 3 dapat diketahui bahwa data yang diuji dalam penelitian ini berdistribusi normal dengan nilai Asymp. Sig. (2-tailed) sebesar 0,258 lebih besar dari nilai signifikansi 0,05. Hasil uji autokorelasi menunjukkan nilai dw yang dihasilkan sebesar 2,031. Oleh karena jumlah $n=156$ dan $k=5$. Pada tabel Durbin-Watson diperoleh nilai $\mathrm{d}_{\mathrm{L}}=1,6727$ dan $\mathrm{d}_{\mathrm{U}}=1,8048$ sehingga diperoleh juga nilai $4-\mathrm{d}_{\mathrm{U}}=2,1952$, maka dapat dirumuskan kriteria $\mathrm{d}_{\mathrm{U}}<\mathrm{dW}<4$ $\mathrm{d}_{\mathrm{U}}$ yaitu $(1,8048<2,031<2,1952)$. Hasil uji multikolinearitas menunjukkan bahwa semua variabel independen memiliki nilai tolerance $>0,1$ dengan nilai $\mathrm{VIF}<10$ maka disimpulkan bahwa data penelitian terbebas dari multikolinearitas. Hasil uji heteroskedastisitas menunjukkan bahwa nilai signifikansi semua variabel bernilai lebih besar dari tingkat signifikansi 0,05 , menunjukkan tidak adanya gejala heteroskedastisitas dalam penelitian ini. Berdasarkan keempat uji asumsi klasik ini maka penelitian layak untuk dilanjutkan.

Moderated Regression Analysis (MRA) digunakan dalam model persamaan regresi linear berganda untuk mengetahui kemampuan kompleksitas operasi perusahaan dalam memoderasi pengaruh pergantian auditor dan financial distress terhadap audit delay. Hasil rekapitulasi uji Moderated Regression Analysis pada penelitian ini disajikan sebagai berikut. 


\section{Tabel 4.}

Rekapitulasi Hasil Uji Moderated Regression Analysis

\begin{tabular}{|c|c|c|c|c|c|}
\hline \multirow[t]{2}{*}{ Model } & \multicolumn{2}{|c|}{$\begin{array}{l}\text { Unstandardized } \\
\text { Coefficients }\end{array}$} & \multirow{2}{*}{$\begin{array}{c}\begin{array}{c}\text { Standardized } \\
\text { Coefficients }\end{array} \\
\text { Beta }\end{array}$} & \multirow[t]{2}{*}{$\mathbf{t}$} & \multirow[t]{2}{*}{ Sig. } \\
\hline & B & Std. Error & & & \\
\hline (Constant) & 67.592 & 2.371 & & 28.507 & .000 \\
\hline $\mathrm{X} 1$ & 2.170 & 2.742 & .068 & .791 & .430 \\
\hline $\mathrm{X} 2$ & 38.345 & 8.857 & .393 & 4.329 & .000 \\
\hline X3 & .298 & .170 & .366 & 1.756 & .081 \\
\hline X1.X3 & .057 & .159 & .063 & .359 & .720 \\
\hline X2.X3 & -1.508 & .801 & -.436 & -1.882 & .062 \\
\hline Adjusted $\mathrm{R}^{2}$ & & & & & 0,091 \\
\hline $\mathrm{F}_{\text {hitung }}$ & & & & & 4,110 \\
\hline Sig. F & & & & & 0,002 \\
\hline
\end{tabular}

Melalui pengujian Moderated Regression Analysis pada Tabel 4 diatas, maka dihasilkan persamaan regresi sebagai berikut.

$\mathrm{AD}=67,592+2,170 \mathrm{X} 1+38,345 \mathrm{X} 2+0,298 \mathrm{X} 3+0,057 \mathrm{X} 1 * \mathrm{X} 3-1,508 \mathrm{X} 2 * \mathrm{X} 3$

Nilai koefisien regresi pergantian auditor (X1) sebesar 2,170, koefisien regresi bertanda positif memiliki arti apabila terjadi pergantian auditor maka probabilitas terjadinya penambahan audit delay menjadi semakin meningkat. Nilai koefisien regresi financial distress (X2) sebesar 38,345 memiliki arti bahwa apabila financial distress naik sebesar satu satuan, maka audit delay meningkat sebesar 38,345 satuan dengan asumsi variabel lainnya konstan. Nilai koefisien moderasi $\mathrm{X} 1 * \mathrm{X} 3$ sebesar 0,057 , koefisien regresi bertanda positif mengindikasikan bahwa setiap terjadi peningkatan antara pergantian auditor dengan kompleksitas operasi perusahaan, maka audit delay akan mengalami peningkatan dengan asumsi variabel lainnya konstan. Nilai koefisien moderasi $\mathrm{X} 2 * \mathrm{X} 3$ sebesar $-1,508$, koefisien regresi bertanda negatif mengindikasikan bahwa setiap terjadi peningkatan antara financial distress dengan kompleksitas operasi 
perusahaan, maka audit delay akan mengalami penurunan dengan asumsi variabel lainnya konstan.

Berdasarkan Tabel 4 diatas dapat diketahui bahwa nilai dari uji $\mathrm{F}$ sebesar 4,110 dan nilai Sig.F yakni 0,002 lebih kecil dari nilai $\alpha=0,05$. Hal ini menunjukkan bahwa model persamaan regresi yang digunakan dalam penelitian ini layak untuk digunakan sebagai alat analisis untuk menguji pengaruh variabel independen dan variabel moderasi pada variabel dependen. Pada Tabel 4 diatas, dapat dilihat bahwa koefisien determinasi yang dilihat melalui nilai adjusted $R^{2}$ memiliki nilai sebesar 0,091 dimana memiliki arti bahwa 9,1\% variasi perubahan audit delay dapat dijelaskan oleh variabel pergantian auditor, financial distress, interaksi antara pergantian auditor dan kompleksitas operasi perusahaan, serta interaksi antara financial distress dan kompleksitas operasi perusahaan. Sisanya sebesar 90,9\% dipengaruhi oleh variabel lain diluar dari model yang digunakan.

Hipotesis pertama $\left(\mathrm{H}_{1}\right)$ berdasarkan Tabel 4 diperoleh nilai signifikansi uji t dari variabel pergantian auditor (X1) sebesar 0,430 lebih besar dari $\alpha=0,05$. Hal ini mengindikasikan bahwa pergantian auditor tidak berpengaruh terhadap audit delay, sehingga hipotesis pertama dalam penelitian ini ditolak. Tidak berpengaruhnya pergantian auditor tehadap audit delay mengindikasikan bahwa auditor telah melakukan perencanaan audit dengan matang atau baik. Auditor yang menerima klien baru akan mempertimbangkan hal-hal penting seperti pemahaman bisnis klien, kondisi perusahaan, materialitas, dan risiko audit yang akan dihadapi sebelum mengaudit suatu perusahaan. Dalam banyak kasus, 
keputusan untuk menerima klien dibuat dalam waktu enam hingga sembilan bulan sebelum tahun fiskal klien berakhir (Tambunan, 2014).

Auditor yang menerima penugasan untuk pertama kalinya juga harus membuat perencanaan audit. Perencanaan audit berisi strategi audit yang akan digunakan untuk pelaksanaan dan penentuan ruang lingkup audit. Pelaksanaan pengujian audit dimulai dari akhir tahun fiskal sementara penerimaan klien dan perencanaan audit dilakukan sebelum tahun fiskal sehingga auditor memiliki banyak waktu untuk mempersiapkan perencanaan yang matang sebelum melakukan pengujian (Megayanti dan Budiartha, 2016). Hasil penelitian ini sejalan dengan penelitian yang dilakukan Putra dan Sukirman (2014), Megayanti dan Budiartha (2016), serta Tambunan (2014) yang menemukan bahwa pergantian auditor tidak berpengaruh terhadap audit delay. Namun, hasil penelitian ini bertentangan dengan penelitian yang dilakukan oleh Rustiarini dan Sugiarti (2013), Praptika dan Rasmini (2016), serta Verawati dan Wirakusuma (2016) yang menyatakan bahwa pergantian auditor berpengaruh positif terhadap audit delay.

Hipotesis kedua $\left(\mathrm{H}_{2}\right)$ berdasarkan Tabel 4 diperoleh nilai signifikansi uji $\mathrm{t}$ dari variabel financial distress (X2) sebesar 0,000 lebih kecil dari $\alpha=0,05$ serta nilai koefisien regresi sebesar 38,345. Hal ini mengindikasikan bahwa financial distress berpengaruh positif dan signifikan terhadap audit delay, sehingga hipotesis kedua dalam penelitian ini diterima. Kondisi financial distress yang terjadi pada perusahaan dapat meningkatkan risiko audit pada auditor independen khususnya risiko pengendalian dan risiko deteksi. Dengan meningkatnya risiko 
ISSN: 2302-8556

E-Jurnal Akuntansi Universitas Udayana

Vol.25.2.November (2018): 1205-1233

itu maka auditor harus melakukan pemeriksaan risiko (risk assessment) sebelum menjalankan proses audit, tepatnya pada fase perencanaan audit (audit planning). Sehingga hal ini dapat mengakibatkan bertambah lamanya proses audit dan berdampak pada bertambahnya audit delay (Praptika dan Rasmini, 2016). Hasil penelitian ini sejalan dengan penelitian yang dilakukan Praptika dan Rasmini (2016) serta Muliantari dan Latrini (2017) yang menyatakan bahwa financial distress berpengaruh positif dan signifikan pada audit delay. Namun, hasil penelitian ini bertentangan dengan penelitian yang dilakukan oleh Julien (2013) yang menyatakan bahwa financial distress tidak memiliki pengaruh terhadap audit report lag.

Hipotesis ketiga $\left(\mathrm{H}_{3}\right)$ berdasarkan Tabel 4 diperoleh nilai signifikansi uji t dari variabel $\mathrm{X} 1 * \mathrm{X} 3$ untuk variabel pemoderasi kompleksitas operasi perusahaan memengaruhi hubungan pergantian auditor terhadap audit delay sebesar 0,720 lebih besar dari $\alpha=0,05$. Hal ini menunjukkan bahwa kompleksitas operasi perusahaan tidak berpengaruh dan tidak dapat memoderasi hubungan pergantian auditor terhadap audit delay, sehingga hipotesis ketiga dalam penelitian ini ditolak. Penelitian yang menguji pengaruh langsung kompleksitas operasi perusahaan terhadap audit delay telah dilakukan oleh Angruningrum dan Wirakusuma (2013) serta Widosari dan Rahardja (2012) yang menghasilkan kompleksitas operasi perusahaan tidak mempunyai pengaruh signifikan terhadap audit delay. Temuan penelitian ini memberikan tambahan bukti empiris bahwa kompleksitas operasi bukan merupakan variabel yang berpengaruh langsung dan juga bukan variabel pemoderasi. 
Hal tersebut dapat disebabkan karena pada dasarnya auditor independen telah memiliki pengetahuan dan keterampilan mengaudit sebagai salah satu standar profesi yang dapat diterapkan dalam berbagai industri. Kompleksitas operasi dalam suatu perusahaan sudah diatasi oleh auditor sebelum melakukan pemeriksaan. Sehingga, auditor telah membuat perencanaan audit yang sesuai dengan kondisi dari perusahaan. Maka dari itu, waktu yang diperlukan auditor dalam penyelesaian audit tidak lama. Sehingga apabila perusahaan yang memiliki kompleksitas operasional tinggi melakukan pergantian auditor tidak akan berpengaruh terhadap lamanya waktu penyelesaian audit.

Kompleksitas operasi perusahaan tidak dapat memoderasi hubungan antara pergantian auditor terhadap audit delay juga dapat disebabkan karena dalam penelitian ini kompleksitas operasi perusahaan diproksikan dengan jumlah anak perusahaan. Dalam praktiknya mungkin saja perusahaan anak diaudit oleh tim audit yang berbeda dan oleh KAP yang berbeda, maka pelaksanaan dan penerapan prosedur audit dilakukan secara bersamaan oleh beberapa tim audit. Sehingga tidak akan berpengaruh terhadap lamanya waktu penyelesaian audit dan berdampak terhadap audit delay.

Hipotesis keempat $\left(\mathrm{H}_{4}\right)$ berdasarkan Tabel 4 diperoleh nilai signifikansi uji t dari variabel $\mathrm{X} 2 * \mathrm{X} 3$ untuk variabel pemoderasi kompleksitas operasi perusahaan memengaruhi hubungan financial distress terhadap audit delay sebesar 0,062 lebih besar dari $\alpha=0,05$. Hal ini menunjukkan bahwa kompleksitas operasi perusahaan tidak berpengaruh dan tidak dapat memoderasi hubungan financial distress terhadap audit delay, sehingga hipotesis keempat dalam penelitian ini 
ISSN: 2302-8556

E-Jurnal Akuntansi Universitas Udayana

Vol.25.2.November (2018): 1205-1233

ditolak. Penelitian yang menguji pengaruh langsung kompleksitas operasi perusahaan terhadap audit delay telah dilakukan oleh Arizona (2012) yang menghasilkan kompleksitas operasi perusahaan tidak memiliki hubungan dengan audit delay.

Perusahaan yang memiliki banyak anak perusahaan cenderung akan memilih auditor yang sudah memiliki reputasi yang baik (Puspitasari dan Latrini, 2014). Auditor telah mengantisipasi kompleksitas operasional perusahaan saat perusahaan memiliki anak perusahaan baru. Ketika perusahaan yang memiliki peningkatan dalam kompleksitas operasionalnya dan kemudian perusahaan tersebut mengalami financial distress maka auditor yang ditunjuk pasti telah menyediakan waktu sesuai dengan kebutuhan jangka waktu untuk menyelesaikan proses pengauditan utang. Dimana auditor telah terlebih dahulu akan mempertimbangkan ketersediaan sumber daya manusia maupun peralatan yang digunakan selama melakukan audit. KAP dapat mengupayakan adanya penambahan tenaga audit yang lebih banyak atau mendatangkan auditor yang lebih berkompeten, sehingga proses audit diharapkan selesai tepat waktu.

\section{SIMPULAN}

Berdasarkan hasil pembahasan penelitian diatas, simpulan dari penelitian ini yaitu pergantian auditor tidak berpengaruh terhadap audit delay, financial distress berpengaruh positif dan signifikan terhadap audit delay, kompleksitas operasi perusahaan tidak memoderasi pengaruh pergantian auditor terhadap audit delay, dan kompleksitas operasi perusahaan tidak memoderasi pengaruh financial distress terhadap audit delay. 
Berdasarkan hasil penelitian dan simpulan diatas maka saran yang dapat diberikan yaitu bagi auditor diharapkan dalam menghadapi perusahaan yang mengalami kondisi financial distress dalam penugasan auditnya dapat mengupayakan adanya penambahan tenaga audit yang lebih banyak atau mendatangkan auditor yang lebih berkompeten. Penambahan tenaga audit tersebut penting dilakukan karena auditor yang ditugaskan pada perusahaan yang mengalami financial distress, harus dapat melakukan penerapan audit dengan sangat hati-hati, teliti, dan cermat, kemudian seorang auditor mengambil ruang sampel yang lebih luas sehingga proses audit diharapkan selesai tepat waktu.

Peneliti selanjutnya diharapkan menggunakan pengukuran audit delay yang lebih tepat dengan menghitung hari penyelesaian audit oleh auditor berdasarkan tanggal yang tercantum dalam kontrak perikatan antara klien dengan auditor. Apabila auditor menyelesaikan audit melewati tanggal yang telah disepakati dalam kontrak perikatan, maka hal tersebut bisa dianggap sebagai keterlambatan penyelesaian audit. Hal ini terkait dengan keterbatasan dalam penelitian ini yang menggunakan pengukuran audit delay secara kuantitatif dalam jumlah hari, dihitung dari tanggal tutup buku sampai tanggal pada laporan auditor. Seharusnya, audit delay merupakan jumlah hari keterlambatan penerbitan laporan audit dari tanggal yang disepakati pada perikatan audit.

\section{REFERENSI}

Ahmed dan Hossain. 2010. Audit Report Lag: A Study of the Bangladeshi Listed Companies. ASA University Review, 4(2), 50-56.

Angruningrum, Silvia dan Made Gede Wirakusuma. 2013. Pengaruh Profitabilitas, Leverage, Reputasi KAP, dan Komite Audit Pada Audit Delay. E-Jurnal Akuntansi Universitas Udayana, 5(2), 251-270. 
Ariyani, Ni Nyoman Trisna Dewi dan I Ketut Budiartha. 2014. Pengaruh Profitabilitas, Ukuran Perusahaan, Kompleksitas Operasi Perusahaan, dan Reputasi KAP Terhadap Audit Report Lag Pada Perusahaan Manufaktur. E-Jurnal Akuntansi Universitas Udayana, 8(2), 217-230.

Arizona, I Putu Edy. 2012. Hubungan Kompleksitas Operasi dengan Audit Delay Perusahaan Publik yang Terdaftar di BEI. Tesis Fakultas Ekonomi Universitas Udayana.

Ashton, Robert H., John J. Willingham, and Robert K. Elliott. 1987. An Empirical Analysis of Audit delay. Journal of Accounting Research, 25 (2), 275-292.

Aziz, M. A. dan Dar, H. A. 2006.Predicting Corporate Bankruptcy: Where We Stand? Corporate Governance, 6(1),18-33.

Baldwin, C.Y. dan Scott P.M. 1983. The Resolution of Claims in Financial Distress: The Case of Massey-Ferguson. Journal of Finance, 38(2), 505516.

Darmawan, I Putu Yoga dan Ni Luh Sari Widhiyani. 2017. Pengaruh Ukuran Perusahaan, Kompleksitas Operasi Perusahaan, dan Komite Audit Pada Audit Delay. E-Jurnal Akuntansi Universitas Udayana, 21(2), 254-282.

Elloumi, F. and Gueyie, J.P. 2001. Financial Distress and Corporate Governance: An Empirical Analysis Corporate Governance. The International Journal of Business in Society, 1(1), 15-23.

Hashim, U. J. B., \& Rahman, R. B. A.2011. Audit Report Lag and The Effectiveness Of Audit Committee Among Malaysian Listed Companies. International Bulletin of Business Administration, 10(10), 50-61.

Hassan, Yousef Mohammed. 2016. Determinants Of Audit Report Lag: Evidence From Palestine. Journal of Accounting in Emerging Economies, 6(1), 1332.

Hossain, Monirul Alam dan Peter J. Taylor. 1998. An Examination of Audit Delay: Evidence from Pakistan.

Jensen, M.C. dan W.H. Meckling. 1976. Theory of the Firm: Managerial Behavior, Agency Costs and Ownership structure. Journal of Financial Economics, 3(4), 305-360.

Julien, Ricco Francois. 2013. Pengaruh Tingkat Profitabilitas, Financial Distress, dan Pelaporan Rugi Bersih Klien Terhadap Audit Report Lag Perusahaan Manufaktur yang Terdaftar di Bursa Efek Indonesia. Skripsi Sarjana 
Jurusan Akuntansi pada Fakultas Ekonomi dan Bisnis Universitas Lampung.

Kontan. 2013. Ada 52 Emiten yang Belum Serahkan Lapkeu 2012. http://investasi.kontan.co.id. Diakses 7 Nopember 2017.

Kontan. 2014. 57 Emiten Belum Menyerahkan Laporan Keuangan 2013. http://investasi.kontan.co.id. Diakses 7 Nopember 2017.

Liputan6. 2016. Belum Sampaikan Laporan Tahunan, BEI Beri Sanksi Ke 63 Emiten. http://bisnis.liputan6.com. Diakses 7 Nopember 2017.

Megayanti, Putu dan I Ketut Budiartha. 2016. Pengaruh Pergantian Auditor, Ukuran Perusahaan, Laba Rugi, dan Jenis Perusahaan Pada Audit Report Lag. E-Jurnal Akuntansi Universitas Udayana, 14(2), 1481-1509.

Merdeka. 2012. 54 Emiten Terlambat Sampaikan Laporan Keuangan 2011. http://www.merdeka.com. Diakses 7 Nopember 2017.

Muliantari, Ni Putu Indah Ayu dan Made Yenni Latrini. 2017. Ukuran Perusahaan Sebagai Pemoderasi Pengaruh Profitabilitas, dan Financial Distress Terhadap Audit Delay Pada Perusahaan Manufaktur. E-Jurnal Akuntansi Universitas Udayana, 20(03), 1875-1903.

Neraca. 2015. Payah, 52 Emiten Telat Laporkan Keuangan. http://www.neraca.co.id. Diakses 7 Nopember 2017.

Owusu-Ansah. S. 2000. Timelines of Corporate Financial Reporting in Emerging Capital Market: Empirical Evidence 23 from Zimbabwe Stock Exchange. Accounting and Bussiness Research,30(3),241-254.

Platt, H. D., \& Platt, M. B.2002. Predicting corporate financial distress: Reflections on choice-based sample bias. Journal of Economics and Finance, 26(2), 184-199.

Praptika, Putu Yulia Hartanti dan Ketut Rasmini. 2016. Pengaruh Audit Tenure, Pergantian Auditor, dan Financial Distress Pada Audit Delay Pada Perusahaan Consumer Goods. E-Jurnal Akuntansi Universitas Udayana, 15(3), 2052-2081.

Puspitasari, Ketut Dian dan Made Yeni Latrini.2014. Pengaruh Ukuran Perusahaan, Anak Perusahaan, Leverage, dan Ukuran KAP Terhadap Audit Delay. E-Jurnal Akuntansi Universitas Udayana, 8(2), 283-299. 
Putra, Angga Brillian Susetyo dan Sukirman. 2014. Opini Auditor, Laba atau Rugi Tahun Berjalan, Auditor Switching dalam Memprediksi Audit Delay. Accounting Analysis Journal, 3(2), 187-193

Ross, S. A. 1977. The Determination of Financial Structure: The IncentiveSignalling Approach. The Bell Journal of Economics, 8(1), 23-40.

Rustiarini, Ni Wayan dan Ni Wayan Mita Sugiarti.2013. Pengaruh Karakteristik Auditor, Opini Audit, Audit Tenure, Pergantian Auditor Pada Audit Delay. Jurnal Ilmiah Akuntansi dan Humanika, 2(2), 657-675 .

Saputri, Oviek Dewi 2012. Analisis Faktor-Faktor yang Memengaruhi Audit Delay: Studi Empiris Pada Perusahaan-Perusahaan yang Terdaftar di Bursa Efek Indonesia. Skripsi Sarjana Jurusan Akuntansi pada Fakultas Ekonomi Universitas Diponegoro, Semarang.

Srimindarti, Ceacilia. 2006. Opini Audit dan Pergantian Auditor: Kajian Berdasarkan Resiko, Kemampuan Perusahaan, dan Kinerja Auditor. Fokus Ekonomi, 5(1), 64-76.

Sugiyono. 2016. Metode Penelitian Bisnis. Bandung: Alfabeta.

Tambunan, Pinta Uli. 2014. Pengaruh Opini Audit, Pergantian Auditor dan Ukuran Kantor Akuntan Publik Terhadap Audit Report Lag. Skripsi Sarjana Jurusan Akuntansi pada Fakultas Ekonomi Universitas Negeri Padang, 3(1), 1-16.

Verawati, Ni Made Adhika dan Made Gede Wirakusuma. 2016. Pengaruh Pergantian Auditor, Reputasi Kap, Opini Audit dan Komite Audit Pada Audit Delay. E-Jurnal Akuntansi Universitas Udayana, 17(2), 1083-1111.

Whitaker, R.B. 1999. The Early Stages of Financial Distress. Jounal of Economics and Finance, 23 (2), 123-133.

Widosari, ShintaAltia dan Rahardja. 2012. Analisis Faktor-Faktor yang Berpengaruh Terhadap Audit Delay Pada Perusahaan Manufaktur di Bursa Efek Indonesia Tahun 2008-2010. Diponegoro Journal Of Accounting. 1(80), 1-13.

Widyastuti, Made Tika dan Ida Bagus Putra Astika. 2017. Pengaruh Ukuran Perusahaan, Kompleksitas Operasi Perusahaan dan Jenis Industri Terhadap Audit Delay. E-Jurnal Akuntansi Universitas Udayana, 18(2), 1082-1111.

Wruck, K. 1990. Financial Distress, Reorganization, and Organizational Efficiency. Journal of Financial Economics, 27, 419-444. 